Rhode Island College

Digital Commons @ RIC

$1-1-2017$

\title{
What Does It Mean to be well? Understanding the Acehnese Youth Refugees' Resettlement Experience
}

\author{
Fairuziana Humam \\ Universitas Indonesia, fairuz.humam@gmail.com \\ Traci L. Weinstein \\ Rhode Island College, tweinstein@ric.edu \\ Holly L. Angelique \\ Penn State Harrisburg
}

Follow this and additional works at: https://digitalcommons.ric.edu/facultypublications

Part of the Psychology Commons

\section{Citation}

Humam, F., Weinstein, T., \& Angelique, H. (2017). What Does It Mean to be well? Understanding the Acehnese Youth Refugees' Resettlement Experience. Antropologi Indonesia, 38(1).

This Article is brought to you for free and open access by the Faculty Scholarship at Digital Commons @ RIC. It has been accepted for inclusion in Faculty Publications by an authorized administrator of Digital Commons @ RIC. For more information, please contact digitalcommons@ric.edu. 


\title{
What Does It Mean to be well? Understanding the Acehnese Youth Refugees' Resettlement Experience
}

\author{
Fairuziana Humam ${ }^{1}$, Traci L. Weinstein ${ }^{2}$, and Holly L. Angelique ${ }^{2}$ \\ ${ }^{1}$ Universitas Indonesia, ${ }^{2}$ Penn State Harrisburg \\ fairuz.humam@gmail.com
}

\begin{abstract}
Abstrak
Studi kualitatif ini menggambarkan persepsi mengenai kesejahteraan para pengungsi Aceh yang tiba di Amerika Serikat sebagai remaja dan menetap di negara bagian Atlantik tengah. Aceh adalah sebuah provinsi di ujung barat Indonesia yang terdiri atas sekitar empat juta penduduk. Selama tahun 1990 sampai 2005, sekitar 20.000 orang meninggalkan provinsi ini karena konflik politik dan mencari suaka di Malaysia, negara tetangga mereka, sebelum dapat pindah ke negara ketiga. Partisipan dalam penelitian ini adalah pengungsi Aceh yang dipindahkan ke Amerika Serikat ketika masih berusia remaja pada fase puncak migrasi tersebut. Hasil penelitian ini menyoroti bagaimana pengungsi Aceh memandang banyak perubahan dalam kesejahteraan mereka sejak awal kedatangan mereka sampai sekarang. Studi ini memberikan kontribusi pada literatur tentang studi pengungsi, yang menyoroti transisi perkembangan dari masa kanak-kanak sampai dewasa dan, pada saat bersamaan, transisi budaya dari negara asal ke negara ketiga atau negara tuan rumah.
\end{abstract}

Kata kunci: pengungsi Aceh, kesejahteraan, rasa memiliki, identitas, sistem pendukung ekologi

\begin{abstract}
This qualitative study describes the extent to which there is a perception of wellbeing among Acehnese refugees who arrived as adolescents to the United States and settled in the Mid-Atlantic States. Aceh is a province in Northwestern Indonesia consisting of approximately four million people. During 1990 to 2005, approximately 20,000 people left the province due to political conflict to seek asylum in Malaysia, their neighboring country, before resettling in a third country. The participants in this research study are Acehnese refugees that were resettled to the United States as adolescents during that peak migration phase. Results describe how these Acehnese refugees perceive their resettlement with regards to wellbeing, in general, and the development of their identities, sense of belonging and ecological systems of support, specifically. The results of this study shed light on how these Acehnese refugees perceive the many changes in their wellbeing from the early days of their arrival to present day. This study contributes to the literature on refugee studies, highlighting the developmental transition from childhood to adulthood and, at the same time, the cultural transition from home country to host country.
\end{abstract}

Keywords: Acehnese refugees, wellbeing, sense of belonging, identity, ecological systems of support 


\section{Introduction}

Aceh is a province in Northwestern Indonesia consisting of approximately four million people. During 1990 to 2005, approximately 20,000 people left the province to seek asylum in Malaysia, a neighboring country, due to political conflict. After seeking asylum in Malaysia, a number of Acehnese refugees were resettled by the United Nations High Commissioner on Refugees (UNHCR) throughout Europe, Australia, New Zealand, and the United States.

Previous studies have examined the Acehnese refugees in their initial place of asylum in Malaysia (Nah \& Bunnell, 2005), their political role as a recent diaspora (Missbach, 2011), their social integration as refugees in Vancouver, Canada (Hyndman \& McLean, 2006), and their transnational marriages and the consequential social dimension of their integration in Vancouver, Canada (Brunner et al., 2014). However, research on the experiences of Acehnese refugees in the United States is still limited, and few studies have focused specifically on their experiences as adolescent refugees, which was the age of some refugees during the main wave of their emigration from Aceh. It is essential that we examine the adolescent refugee perspective during this developmental stage and compare it with the perspective of those who went through the relocation process as adults because their cultural and resettlement perspectives are likely to differ greatly.

The Acehnese refugees in the United States are categorized as "involuntary" or "forced" migrants, similar to Vietnamese and Cambodian refugees in the U.S. (Ogbu \& Simons, 1998). The nature of forced migration requires a waiting of several years for refugee applications to be processed, during which time formal education gaps usually occur for children and adolescents who live in a transit country without proper documentation. In addition, the burden of being an adolescent is different compared to younger children who have less family responsibilities. The pre-migration and resettlement processes may also serve as a traumatizing experience for adolescents in particular, which may, in turn, result in adolescent refugees having a higher risk of developing trauma responses, including maladaptive behaviors (Pumariega, 2005).

The current study aims to understand the Acehnese asylum seekers' path towards psychological wellbeing after their arrival in the United States during adolescence. The importance of this task is twofold. First, the traditional model used to study resilience tends to pathologize adolescent refugees by focusing solely on the struggles they face. In contrast, this study presents a strengths-based model of resilience by highlighting how the Acehnese adolescent refugees in the current sample built a path towards wellbeing, particularly through perceived ecological support, sense of belonging, and identity. Second, the findings of the current study add to the small body of empirical literature on the adolescent refugee resettlement experience.

\section{Background}

In the year 2000, thousands of Acehnese sought refuge from the conflict between the Indonesian military and GAM (Gerakan Aceh Merdeka), a local separatist movement seeking independence from Indonesia. When martial law was declared in May 2003, it resulted in mass migration as the Acehnese fled the province to seek asylum in neighboring Malaysia. These asylum seekers travelled on vessels without proper documentation and supplies (Nah \& Bunnell, 2005). As their application for refugee status was being assessed, they were considered illegal migrants and lived under detention. The UNHCR (2005) in Kuala Lumpur recorded a mass influx of 19,523 Acehnese refugees to Malaysia by the end of that year. Some people who had come to Malaysia earlier as economic migrants also became refugees because the situation in Aceh made it unsafe to return to. Furthermore, during the peak migration from Aceh to Malaysia, any Acehnese who lived in 
Malaysia were suspected of being a part of the separatist movement by the Indonesian military, making it even more difficult for them to return (Missbach, 2011).

Many of the Acehnese refugees were arrested and sent to jail by Malaysian authorities, after which they were detained for four to 12 years (Missbach, 2011). This occurred because Malaysia had not signed the Geneva Convention relating to the Status of Refugees of 1951 nor the Protocol Relating to the Status of Refugees of 1967 (UNHCR, 2011). Therefore, Malaysia could not accept refugees as permanent residents or citizens, thus jeopardizing the legal status of Acehnese refugees in Malaysia. Men, women and children were affected by the long pre-migration process of leaving Aceh, life transitions in Malaysia, and the post-migration resettlement process in their final host country. After the resettlement process in host countries, which included Denmark, Sweden, Norway, Canada, Australia, New Zealand, and the United States, the Acehnese settled down and rebuilt their lives as migrants (and then as citizens) in each of these countries.

\section{A Theoretical Model for Wellbeing}

Wellbeing affects the refugee adjustment and adaptation processes to a new country, including how refugees see themselves (identity), where they fit (sense of belonging), and how the social context influences the way they adjust (ecological systems of support). Together, these three developmental factors will either hinder or support their process of attaining wellbeing. The model below describes our proposed wellbeing framework.

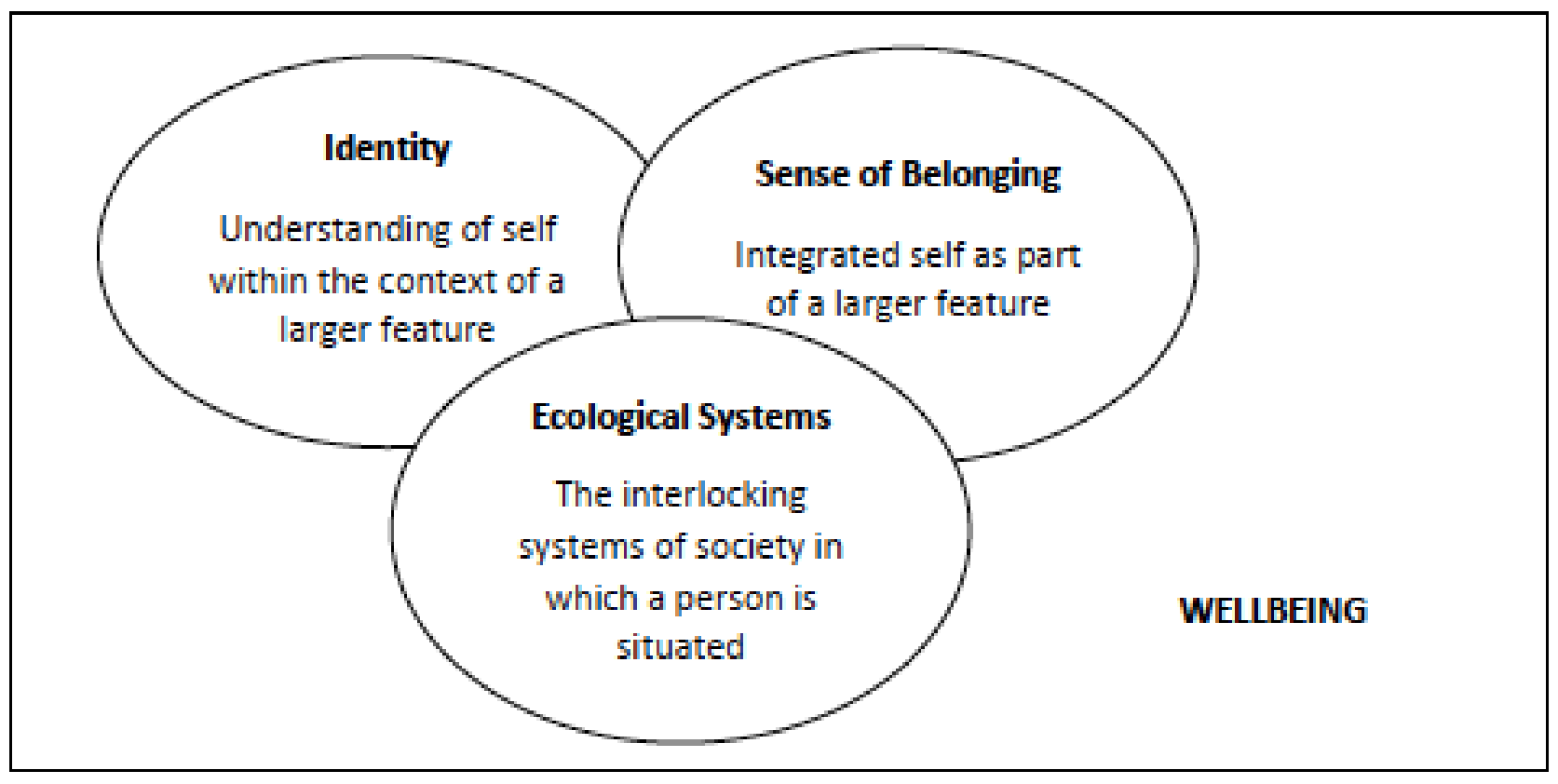

Figure 1. Three-part wellbeing model 
Identity. Multiple components are involved in shaping an individual's identity, including culture, language, education, socioeconomic class, gender, and individual life experiences (Phan et al., 2005). Ethnic identity is an important component of identity for immigrants and refugees, in particular, and can act as a value system that is constructed from interactions within groups and macrosystem settings (Lange \& Westin, 1985). Thus, in order to achieve wellness, refugees must find a balance between identification with their host country and identification with their ethnicity that comes from some form of connection with their native country and/or culture. This process was highlighted in the findings for the current study, in which participants described different paths to achieving American, Acehnese, and AcehneseAmerican identities.

Sense of belonging. Anthias (2006) defined sense of belonging as a feeling that one is part of a social fabric or group. An individual's sense of belonging to an ethnic group is associated to their overall wellbeing. Thus, for immigrants and refugees, a strong individual ethnic identity is associated with having an increased sense of belonging within an ethnic group (Jenkins, 2008; Saylor \& Aries, 1999).

Having a strong sense of belonging has been found to have a positive relationship with positive wellbeing for ethnic minority populations, including immigrants and refugees (Hagerty, et.al, 1992). Wain (1981) explored some of the problems that refugees in the United States expressed regarding their sense of belonging, including difficulty in understanding the American way of life and sense of "differentness." Those difficult experiences created a sense of being an "other" rather than being a "part" of the host community. Since the Acehnese in the United States are considered to be an ethnic minority, it is expected that their sense of belonging is important to the overall wellbeing of Acehnese refugees.

Contextualizing refugee experiences within ecological systems of support can enhance our understanding of how identity and sense of belonging impact wellbeing, especially for refugees. A person's wellbeing cannot be solely attributed to the individual, but rather as contextual and influenced by many layers of interactions between an individual and their surroundings (see Figure 1). For adolescent immigrants and refugees, schools are an important context that links their sense of belonging to larger ecological systems, a notion supported by the current study's findings.

Ecology. Contextualizing refugee experiences within ecological systems of support furthers our understanding of refugee wellbeing that goes beyond individual experiences. The ecological approach posits that there are greater influences beyond the individual that may enhance or hinder refugees' ability to achieve wellbeing. More specifically, no individual lives in a vacuum. Instead, they are impacted upon by other systems, such as family, peers, school or work, and the larger society. These systems are especially relevant to the development of wellbeing for immigrants and refugees.

For example, Correa, Gifford, and Barnett (2010) developed an ecological model of the family system for adolescent refugees in order to better comprehend the impact of family in social inclusion. According to this model, the adolescent refugee's relationship with their parents, and their comfort at home, play a vital role in the development of individual wellbeing. Further, family plays an important role in the adolescent refugee's adaptation to the host country. The family's inclusion or marginalization in the community, at times aided by the behavior of the adults in the family, affects the adolescent's development of wellbeing. As another example, the ability of the parents to include the family in cultural or religious organizations in the community may impact the development of wellbeing for youth in the home. In fact, religion was an important theme in the findings for the current study, in which access to a religious community or organization served as an important path to overall wellbeing. 


\section{Adolescent Wellbeing}

Most existing research about Acehnese refugees examines the adult refugee experience, such as support system development, and the adjustment process in an urban context from Aceh to Vancouver, Canada (Hyndman \& McLean, 2006). The literature includes an examination of the development of political and nonpolitical organizations of the Acehnese diaspora (Missbach, 2011) and the social integration of adults in the host country that stems from transnational marriages (Brunner et al., 2014). There is a gap in the literature, in which research examining Acehnese refugees' psychological wellbeing, an essential aspect of the refugee experience, has been neglected. Furthermore, studying this experience from an adolescent perspective adds an additional dimension to our understanding of the developmental nature of wellbeing through transnational relocation from home to host country.

Arrival to the host country as an adolescent refugee involves a diverse range of experiences related to wellbeing, including developmental changes from child to adult and cultural changes from the home country to the host country - a process that may at times involve a transit country between the point of departure and final destination. Consequently, it is not unusual for adolescents going through this process to go through a phase of experiencing an identity crisis (e.g., Rousseau, 1995). From a developmental perspective, research does support the notion that immigrants who relocate between the ages of 13 to 17 years old face more problems related to adaptation compared to their peers who arrive at younger ages (Rumbaut, 2004). In addition, refugees undergo an adaptation process to a new culture that commonly results in intergenerational stress and family conflict - difficulties that tend to be intensified even during a typical adolescent developmental process without the added stress of having to adapt to a new environment (Earnest, Housen, \& Gillieatt, 2007; Hyman, Vu \& Beiser, 2000; Pumariega et al., 2005). For adolescent refugees, problems that are of particular concern may arise from these stressors of adaptation, such as increases in substance abuse and acting out (e.g., aggressive) behaviors (Arroyo \& Eth, 1985). Thus, the risk of chronic psychopathology is present for the adolescent refugee whose entire world is changing (Pumariega et al., 2005).

However, looking at additional results over the long-term, it seems that adolescents fare neither worse nor better than refugees who arrived as adults, particularly with regard to educational and occupational attainment (Rumbaut, 2004). Given these seemingly conflicting outcomes, the current study seeks to understand the wellbeing of the Acehnese adolescent refugees, from the perspective of their developmental and cultural transitions.

\section{Data \& Analysis}

The purpose of this study was to examine the developmental path to wellness for Acehnese refugees who came to the United States as adolescents. Participants of this research study included one Acehnese man and three Acehnese women who came to the U.S. between the ages of 13 to 17 years old, during the mass migration out of Aceh that occurred between 1990 and 2005 with the assistance of the UNHCR. All participants now live in the Central Pennsylvania and Maryland areas, and have gained either permanent residency or citizenship status in the U.S. Typical Acehnese names have been used as pseudonyms in place of the participants' real names. All four participants described themselves as Muslim and were between the ages of 25 to 30 years old when the study was conducted.

Given the limited number of Acehnese refugees in the area, which is approximately 25 families, only seven adults met the criteria for this study. There were limited resources available to conduct the study outside of the Maryland and Pennsylvania area. Three participants chose not to participate, leaving only four persons who could be included in the current study. The other Acehnese refugees in the area were excluded because they were either too old (above the age 
of 17) or too young (below the age of 13) upon arrival. One participant was 18 years old when he arrived in the US. The participant is included in the study because he was an adolescent during the asylum seeking process. Furthermore, the participant experienced the cultural transition into the educational setting of a US high school, which is an experience that is similar to the other participants. Each of the participants' experiences in the current study varies from one to the other, and the small sample size limits the possibility of making broad generalizations of the Acehnese adolescent refugee experience in the U.S. However, the participants also have many experiences in common, and some significant themes emerge from the data, which are analyzed here.

Participants were interviewed at their homes, which was their desired location, for up to two hours. Interviews were conducted in English and tape recorded. A basic sociodemographic form was filled out by the participants before the interview process started. During the interview, participants were given the following prompts:

- Tell me about your arrival in the United States as a refugee.

- What were the important aspects that helped or hindered your wellbeing at that time?

- Tell me how things have changed since you first arrived until now.

Additional prompts were included to capture several aspects of wellbeing: whether they felt as though they belonged in the U.S. or like an outsider; what aspects of life (school, family, religion, work, or other) affected their wellbeing; at what times did they feel like an American or an Acehnese; and how do they feel about being a former refugee. In these interviews, it was important for participants to describe "wellbeing" using their own terms.

\section{A Path to Wellness}

Analysis was conducted using grounded theory. Themes emerged from the data in which participants' revealed related information that formed common themes. The main themes that emerged from the data aligned with our proposed model of wellness: religion (identity à sense of belonging à ecological systems), school experiences (sense of belonging à ecological systems), and adult life (identity à sense of belonging). Religion was a major theme that was important to participants throughout their lifespan, from the time they arrived in the U.S. as adolescents to later when they became adults, involving multiple ecological systems of supports that incorporated sense of belonging and individual identity. Their school experiences became an important foundation of their initial experiences as adolescent refugees in the U.S., impacting sense of belonging and incorporating multiple ecological systems of support. Lastly, becoming an adult in America was a common theme, especially important as they described their current life, along with different ways of seeking wellbeing in Acehnese American adulthood. This last theme involved identity development and sense of belonging as paths to overall wellness for participants.

Religion. Religion was the predominant theme that ran throughout the participants' responses about their paths to wellbeing. These paths can be understood through intersecting frameworks of identity, sense of belonging, and ecological systems of support. One finding was that Acehnese refugees identified themselves more closely with an Islamic identity rather than Acehnese or even Indonesian identities. Most of the participants utilized religion as their value system, even when they no longer practiced it. For example, Kemala turned to religion in difficult times. She viewed her life of hardship as a test from God. "The religion, I think if we are far from Allah, I don't think I am still here. I mean a lot of stress out there. You know what I say, this is cobaan [a test]. This is a test from Allah, right. So you just go to, wherever." In contrast, Umar had a strong religious education in primary school, but he chose to be more religious after living in the U.S. than he used to be when he was back in Aceh. For Umar, religion "protected" 
him from becoming too American:

"It [religion] helped you to stay away from turning to really, really American. Because if you don't have them around, you're gonna be different. You're gonna celebrate Christmas, you're gonna celebrate Thanksgiving, or I mean, Halloween and something like that. You're gonna go to club, you're gonna start having beer in your house if you don't have them already."

We also learned from Umar that the participants' age, gender, and the year they entered the U.S. influenced the way they perceived and experienced religion. The other participants, who were younger than Umar when they came to the U.S., tended to not have the same prior religious education as Umar. Consequently, they were less able to relate to the practice of religion compared to Umar.

Developmental issues in practicing religion were influenced by both individual (self) choices and ecological (societal) forces. For example, Mutia struggled with both religious identity and belonging over time: "Of course, something that has changed dramatically is the religious aspect. Um, because I do what my parents tell me to do when I was younger. And then as I grow older, and learn different things, and kinda develop opinion on your own, you just changed based on what you think, um, other things, maybe school." She also struggled with developing a religious identity:

"They would expect me to, do what Muslims do. Pray, five times a day, read the Qur'an, cover your aurat [parts of the body that should be covered based on the Islamic law] and stuff. But I, I just feel that, because I don't know much about the religion, I didn't study about it. Everything comes from my parents, what they know, they teach me, so that's just something that I would love to improve on in the future. Because right now I just feel like... I just want to do what I want to do".

For participants in this study, practicing religion was perceived as a way to feel closer to God and was cited as a major part of the path to wellbeing. But for some participants, like
Mutia and Kemala, practicing religion without understanding the purpose of the practice also posed a challenge. Gibson (2002) explained that the older an adolescent refugee arrives, the stronger they feel about their self-identity; thus, the formation of a religious identity was a struggle for some of the participants due to external ecological systems like family. Over the course of discussing their development, however, it was clear that religion was a major aspect of wellbeing for all four participants. This was true even though the religious practices and values were different from one participant to another.

Another strong thread ran throughout the discussion on religion and wellness in the four interviews - that of the events of 9/11. The participants all entered the U.S. after the World Trade Center's Twin Towers in New York City were attacked by extremists in 2001. This event made all of the participants keenly aware that their religion, Islam, and by extension themselves, was being portrayed negatively by the U.S. media and by society in general. But the events of $9 / 11$ did not hinder Dien's choice to cover her head with a hijab:

"I think the only thing that changed to me, people become more sensitive, like I said earlier, now everything is insulting. I guess it's also because of the social media, how the news portray you, they don't know what happened, because I don't remember, it was being like that before, like we get sensitive of the small stuff".

Dien's reference to opinions about Islam in social media and public media was mirrored by Kemala, but with reference to more recent events, as she discussed the 2016 U.S. presidential election. Public hatred toward Muslims made Kemala worry:

"Even though it's not happen that what happen in the news. You know, you gonna feel worry when you go out, what's gonna happen to you. Because people here, we don't know what in their head, what in their heart, right. So if they want to shoot they can shoot anybody".

Due to the events of 9/11, individual identity, sense of belonging, and ecological systems 
of support collided for the participants, and affected them through adulthood. It was the same with the events surrounding the 2016 election of Donald Trump. Although these events affected each of the participants differently, they nevertheless strengthened the importance of the role of religion in their path to wellness for all four participants. For all four participants, the macrosystem of public perceptions and social media surrounding Islam reinforced the participants' need to strengthen religious identity and sense of belonging. Umar, in particular, finds himself developing stronger his religious ties the longer he lives in the U.S. For the three women, understanding the meaning and purpose of religious practices became important.

School experiences. While religion served as a lifetime path to wellness for participants in the current study, school served as a salient, strong, but time-limited influence on wellness, one that each participant struggled with upon arrival in the U.S. School impacted both individual identity developmental, as well as sense of belonging, for the participants in our study. It is worth noting that resettlement in the U.S. came after several years of living under illegal circumstances in Malaysia without any access to education. Thus, entering school in the U.S. marked a new chapter in their lives. At the same time, the school system in the U.S. was ill-equipped to provide them with a smooth transition.

School is the first social environment experienced by the participants in the U.S., and a dominant factor in developing their wellbeing (Goodman et al., 2001; Correa, Gifford, \& Barnett, 2010). The participants' experienced a long education gap, which for one participant lasted up to six years. Lack of familiarity with school, limited English skills, and the typical struggles of acclimating to a new life in a new country negatively affected the participants' school experiences. For Umar, who was the oldest upon arrival, entry into the U.S. school system was a particularly good-dream-turnedbad:

"Starting a school, which is like a, like a dream. Meaning is like, you just don't know that what you doing and you don't understand what they telling you. Basically, every day you just dream. Like you just confused, what's next. And then you wanna say something, you wanna tell something, and then you just don't have any idea."

For students like Umar, school was supposed to be a reliable source of learning for refugees where they can practice their English language skills, learn the American culture, and engage in social interactions. Unfortunately, school proved to be too much of an unfamiliar environment to catch up with for Umar: "It's very hard to follow, to start over, to hold a pen, again. I even have to learn how to write a word that I, I even have to start memorize like the basic math like, um, kali kali [multiplication]."

All participants reported having basic difficulties with math. Umar and Dien eventually had to drop out of school because the educational system did not allow them to continue. Umar was 21 years old when he was in eleventh grade, and when the school found out, they told him that he was too old to continue his schooling. He was never provided with information on adult education.

For others, an "English as a Second Language" (ESL) class created a significant chance for the participants to learn the language and engage with other refugee students. However, the participants felt unsatisfied with the ESL classes. For example, in Kemala's school, they provided ESL as a class in the larger public school but she was not satisfied with the learning content. When she looked to transitioning to University, she was excited about the prospect but did not feel prepared for it:

But you know what is I regret, um, our teacher in high school year, they should focus more on grammar to us, not just reading. Because a lot of reading in ESL class before, and, but when you go to college, you have to take placement test, and when I got on my placement test, it's intermediate.

Thus, the language barrier had hindered their wellbeing early on. This is consistent with 
the literature that cites language as a barrier to developing a sense of belonging (Keyes \& Kane, 2004). English, which is the dominant language in the U.S., was not the native language of the Acehnese refugees. This, ultimately, had become a barrier that hindered them from interacting freely with other people.

Educational barriers aside, the participants experienced social obstacles at school when they tried to interact with mainstream non-ESL students. Feeling different to other students at school became one of the barriers to interacting with their peers at school. Dien described this struggle: "I wish I can speak English like them, fluently, look like them, but then again, because those friends they brought me up, like, no, you don't need to be American, you should be proud of who you are, and my teacher too, you should be proud of who you are, you should be proud of your accent." The support that they received from their social circle at school helped them overcome the struggle to acculturate into the mainstream culture in the U.S.

Participants did note that they received some support from school, such as support from their teachers and the friends they had made at school. These ecological support networks kept Mutia and Kemala in school, and helped forge a new sense of belonging in the U.S. for all participants. The U.S. schools were ultimately unprepared in helping the participants effectively overcome the gap in education that they all experienced while living in asylum in Malaysia. Further, their need to gain higher education to access better opportunities became important tasks for each of the participants as they entered emerging adulthood. For Umar and Dien, the failings of the U.S. school system became obstacles to their wellbeing; for Kemala and Mutia, the ESL setting provided some support for them as they transitioned into adult life.

Becoming an adult. As the participants continued their lives in the U.S., they transitioned into adulthood. In their transition from adolescence to adulthood, the development of identity and a sense of belonging proved important to finding their path to wellness. As adults, they gained more life experiences, such as marriage, working, and living independently, as part of the broader American society. Each participant had unique paths to developing an identity'. For one participant, Mutia, "Acehnese" was an adjective that described her identity, including how she was expected to behave and the goals she was expected to accomplish (e.g., acquire a husband):

"You know, Acehnese, they are trying to preserve [sic] the women, like you have to be proper, properly behave, otherwise you wouldn't get a husband, or whatever. So yeah, they were always watching out for us, like you can't talk like this, you can't behave like this, you have to be a proper woman, do dishes, cooking. I think that was a good aspect because they teach us how to behave properly, and things like we should and shouldn't do. Um, it helps shape us a person and um, so yeah, I am kinda thankful with that, even though it's um, kinda of annoying that we don't get to what other kids get to do."

Mutia describes here the transition from adolescence to adulthood in multiple ways, including the transition from having little freedom to a lot more freedom, decisions about how she should behave and why, and what her role as a woman should be.

It is not surprising that marriage, in particular, was reported as a strong indicator of wellbeing in adulthood for these participants, as this is a value typically passed down in refugee communities, especially those with a strong religious base. When it came to marriage, participants had different paths. Mutia, who married a man from outside of the Acehnese community, did find the freedom she spoke of earlier through her marriage:

"I like being married because of that. Because I get more freedom. I have more freedom when I got married where basically I am not controlled by my husband, whereas, when I was to marry an Acehnese, I would have to be obedient under my husband, like I have to cook, take care of him, um I have to follow what my husband would tell me." 
Umar first married a person from outside the Acehnese community, but later got divorced before remarrying an Acehnese woman.

"Women [characteristic] is always the same. That's what I think. But religion is very important. I always think when I got divorce I stay [single] for a couple years. I wanna married, if I have a chance to marry again, I would marry an Acehnese that understand the religion. Because I think that's what could save me. Safe my marriage. A lot of things have changed. And actually a lot better than it was. A lot better than before. Than even before I was married, I feel like a lot more safe."

Marriage looked different for the different participants, but served as a path to wellness to all who were married. Marriage was an "identity" that signaled success as an adult, but also served as a sense of belonging to another human being, as well as to either their native Aceh community (e.g., Umar) or to another community - that of mainstream American society (Mutia).

Having a sense of belonging in the context of community was important for all participants. Being surrounded by the Acehnese community in America made the participants feel that they still belonged to an Acehnese way of life. For Umar, his sense of belonging to the Acehnese people was one of the main ways that he sought wellbeing. This belonging was exemplified in his portrayal of his marriages above, but also in the following quote:

"I think a lot of people who, stay away from people, you know from their own country, you know, they start living by themselves, or they go somewhere else. You could see them different. I think that's why I always want to get close to people. I think that's why I am being around the Acehnese. It helped me going through and practice, being nice and doing a lot of safe things".

Likewise, Kemala's sense of belonging to Aceh remained even though she felt that she had gotten used to the American way of life because she still did not feel like an American. She thinks that she is still an Acehnese.

“American? I don't feel that. I don't feel that yet, right. Aceh, I am still from there. Only when, the language when we go out there, when we go outside. We use English language. Sometimes they keep speaking English of course. But in home, I feel like in my own country. Like the language, mom here, and the food everything. I mean sometimes we do eat like spaghetti whatever, but I think myself my identity is still Acehnese."

For Kemala, her identity and sense of belonging are tied to the labels that she chooses to use. Her use of English in public indicates a sense of belonging to the American way of life, but her ability to speak her native language at home represents a sense of belonging to Acehnese culture. Thus, she has developed multiple "identities" in different settings, which is commonly accepted as the optimal way of life by refugees.

At the time of interview, the participants all reported that they had achieved wellness, although their paths to wellness were different. The transition from adolescence to adulthood became most apparent with events like marriage, employment, and procuring independent places to live, which are all signs of success as adults. The process of acculturation in the U.S. was also apparent. For example, like living independently was a common sign of "American" success. Our participants described different paths to wellness in which different factors impacted their vision of wellness across the domains of individual identity, sense of belonging, and ecological systems of support.

\section{Conclusion}

With all participants reporting wellbeing across various domains in their lives, it is important to examine what they meant by "wellbeing." For our participants, wellbeing was related to feelings of being free: free of fear, free to express themselves, free to make choices and feeling safe with the choices they made. Here, Umar discusses wellbeing in the form of freedom:

"It's a lot of freedom. There's nothing that 
you could be afraid of, doing this and doing that. There's no neighbors gonna stop you of doing this and that. There's nobody that gonna say something bad to you if you're doing something wrong. It's not like in, it's not like in Indonesia, you don't have to be parents around you tell you, let's say if you're smoke or doing drugs, or anything bad. It's enough to have your, you know neighbor telling you. Or somebody else, you're gonna be, you're gonna scared them. But not here, you're just totally free here."

Freedom was a common theme in all of the interviews. Life in America is identified with having a lot of freedom compared to the life back home. Kemala discussed the new freedom that she experienced in America: "I mean, America is a freedom country, right. So we can do, we have free to speech, free religion what to practice, even though, yeah. Nobody stop me from my religion, what practice for, I mean, basically, look (in reference to her Muslim headscarf)."

Acehnese refugees, who were once adolescent asylum seekers in Malaysia, have made the journey to wellbeing in the United States as adults, even though the path was difficult at times.

Schooling was the biggest challenge for these refugees, in large part due to the large gaps in education that they experienced from the time they spent not attending school while waiting to be relocated to a permanent country of residence. But school also provided a sense of belonging in the U.S. In attaining a sense of belonging, religion helped the participants negotiate between American ideals and personal values from their native culture that were familiar and made sense to them. This process of biculturalism has been shown to aid the development of an integrated identity that promotes healthy psychological adaptation for immigrants and refugees (Phinney et al., 2001). Having a sense of belonging to one's ethnic community and exerting efforts to integrate into the host community are a part of the life process experienced by refugees as seen in our participants' narratives (Lustig et al, 2004; Pumariega et al, 2005; Valtonen, 2004). Integration made it possible for our participants to achieve wellbeing in adulthood, leading to a sense of normalcy to live like every other adult in American society. Feeling connected like this is a fundamental aspect and has important implications for wellbeing (Bornholt, 2000, Hagerty et. al, 1992). Having a sense of normalcy allowed the participants to feel as though they are the same as everybody else in the host country. Dien expresses this sentiment in a very "American" way: "I feel like an American when I hold my credit card and I swipe my card, I feel like an American when I am driving, when I go to school."

\section{References}

Arroyo, W., \& Eth, S.

1985 Children traumatized by central American warfare in S. Eth \& R. Pynoos (Eds.), PostTraumatic Stress Disorder in Children. Washington, D.C.: American Psychiatric Press.

Bornholt, L. J.

2000 Social and Personal Aspects of Self-Knowledge: a Balance of Individuality and Belonging. Learning and Instruction, 10(5): 415-429.

Brunner, L. R., Hyndman, J., \& Mountz, A.

2014 Waiting for a Wife: Transnational Marriages and the Social Dimensions of Refugee Integration. Canada's Journal on Refugees, 30(1). 
Correa-Velez, I., Gifford, S. M., \& Barnett, A. G

2010 Longing to Belong: Social Inclusion and Wellbeing among Adolescent with Refugee Backgrounds in the First Three Years in Melbourne, Australia. Social Science \& Medicine, 71(8): 1399- 1408.

Earnest, J., Housen, T., \& Gillieatt, S.

2007 Adolescent and Young Refugee Perspectives on Psychosocial Wellbeing. Perth: Centre for International Health: Curtin University of Technology.

Gibson, E. C.

2002 The Impact of Political Violence: Adaptation and Identity Development in Bosnian Adolescent Refugees. Smith College Studies in Social Work, 73(1): 29-50.

Goodman, E., Adler, N. E., Kawachi, I., Frazier, A. L., Huang, B., \& Colditz, G. A.

2001 Adolescents' Perceptions of Social Status: Development and Evaluation of a New Indicator. Pediatrics, 108(2): e31-e31.

Hagerty, B. M., Lynch-Sauer, J., Patusky, K. L., Bouwsema, M., \& Collier, P.

1992 Sense of belonging: A Vital Mental Health Concept. Archives of Psychiatric Nursing, 6(3): 172-177.

Hyman, I., Vu, N., \& Beiser, M.

2000 Post-Migration Stresses among Southeast Asian refugees adolescent in Canada:

A Research Note. Journal of Comparative Family Studies, 31(2): $\quad$ 281- 293.

Hyndman, J., \& McLean, J.

2006 Settling like a state: Acehnese Refugees in Vancouver. Journal of Refugee Studies, 19(3): 345-360.

Jenkins, R.

2008 Social identity. 3rd edition. London, U.K: Routledge.

Lange, A., \& Westin, C.

1985 The Generative Mode of Explanation in Social psychological Theories of Race and Ethnic Relations. Research group on ethnic relations, social cognition and cross cultural psychology, Department of Education and Center for Research in International Migration and Ethnicity, Report no.6, Stockholm.

Missbach, A.

2011 Separatist conflict in Indonesia: The Long-Distance Politics of the Acehnese Diaspora (Vol. 39). Routledge

2011 The Acehnese Diaspora after the Helsinki Memorandum of Understanding: Return Challenges and Diasporic Post-Conflict Transformations. Asian Ethnicity, 12(2), 179-201. Doi:10.1080/14631369.2011.571836.

Nah, A. M., \& Bunnell, T

2005 Ripples of Hope: Acehnese Refugees in Post-Tsunami Malaysia. Singapore Journal of Tropical Geography, 26(2), 249-256. 
Ogbu, J. U., \& Simons, H. D.

1998 Voluntary and Involuntary Minorities: A Cultural-Ecological Theory of School Performance with some Implications for Education. Anthropology \& Education Quarterly, 29(2), 155-188.

Phan, L. T., Rivera, E. T., \& Roberts-Wilbur, J.

2005 Understanding Vietnamese Refugee Women's Identity Development from a Sociopolitical and Historical Perspective. Journal of Counseling \& Development, 83(3), 305-312.

Phinney, J. S., Horenczyk, G., Liebkind, K., \& Vedder, P

2001 Ethnic identity, Immigration, and Well-Being: An Interactional Perspective. Journal of Social Issues, 57(3): 493-510.

Pumariega, A. J., Rothe, E., \& Pumariega, J. B.

2005 Mental Health of Immigrants and Refugees. Community Mental Health Journal, 41(5): 581597.

Prilleltensky, I., \& Prilleltensky, O.

2007 Promoting wellbeing: Linking Personal, Organizational, and Community Change. John Wiley \& Sons.

Rousseau, C.

1995. The Mental Health of Refugee Children. Transcultural Psychiatric Research Review, 32(3): 299-331

Rumbaut, R. G.

2004 Ages, Life Stages, and Generational Cohorts: Decomposing the Immigrant First and Second Generations in the United States. International Migration Review, 38(3): 1160-1205.

Saylor, E. S., \& Aries, E.

1999 Ethnic Identity and Change in Social Context. The Journal of Social Psychology, 139(5), 549-566.

Wain, B.

1981 The refused: The agony of the Indochinese refugees. Hong Kong, China: Dow Jones Publishing Co.

United Nations High Commission of Refugees

2011 The 1951 Convention Relating to The Status of Refuges and Its 1967 Protocal. Geneva, Switzerland: United Nations. 